\title{
Regeneration of Brownfield Area and Redundant Technical Culture Buildings to Symbols of Contemporary City
}

\author{
Zrinka Barišić Marenić, Mia Andrašević \\ Faculty of Architecture, University of Zagreb, Zagreb, Croatia
}

\begin{abstract}
Citation: Barišić Marenić Z, Andrašević M. Regeneration of Brownfield Area and Redundant Technical Culture Buildings to Symbols of Contemporary City. SEE J Archit 10.3889/seejad.2016.10014

Key words: Redundant Technical Culture Buildings: Brownfield; Urban Regeneration; Bilbao; Zagreb.

Correspondence: Zrinka Barišić Marenić Faculty of Architecture, University of Zagreb, Zagreb, Croatia. mail: zbarisic@arhitekt.hr

Received: 29-Dec-2015; Revised: 30-Jan-2016; Accepted: 31-Jan-2016; Published: 13-Feb-2016

Copyright: ๑ 2016 Zrinka Barišić Marenić, Mia Andrasević. This is an open-access article distributed License, which permits unrestricted use distribution, an reproduction in any medium, provided the original author and source are credited.

Competing Interests: The author have declared that no competing interests exist.
\end{abstract}

\begin{abstract}
BACKGROUND: Industrial complexes and technical culture complexes are significant morphological elements of the city.

AIM: This paper focuses on the two European towns and showcases: Bilbao in Spain and Zagreb in Croatia.

MATERIAL AND METHODS: The extravagant project of Gehry's started the reformation of the Bilbao with growth of tourism and profit in general. Beside the urban regeneration, it started the trend of star-architects building their masterpieces one next to another along the river Nervion. This paper focuses on two complexes of technical culture buildings in Zagreb, presenting early conversion versus still unsolved regeneration.

RESULTS: Former industrial city of Bilbao is nowadays a symbol of contemporary architecture featured by Guggenheim Museum and designed by Frank Ghery. It featured urban regeneration and numerous other examples of the contemporary architecture. This paper focuses as well on conversion of former wine-storage for mixed-use complex designed by Philippe Starck. The initial idea of the project was to revive the dying neighborhood because of the gentrification caused by the Guggenheim Museum. Zagreb intensive development in recent 150 years is based on industrialization process. After intensive deindustrialization, regeneration of redundant industrial complexes and technical culture buildings is segmented. Although the most prominent regenerations are significant architectural achievements winning the most prominent architectural awards, numerous complexes are awaiting for the conversions. Many of them are left to decay, or were demolished promptly, offering attractive location for new buildings that have been raised. This paper focuses on two complexes of technical culture buildings in Zagreb, presenting early conversion versus still unsolved regeneration. The first one is the avant-garde example of conversion of Tannery building for the Glypthotek of Yugoslav, i.e. Croatian Academy of Science and Art. The other example is Zagreb Fair, which realization since 1955 has initialized urbanization of late modern New Zagreb. Decay of Fair function, led to provisory or designed conversion of pavilions for new purposes, but the integral regeneration still is still missing.
\end{abstract}

CONCLUSION: Urban regeneration should be considered seriously, and lead to transformation to contemporary city of 21 st century.

\section{Introduction}

Industrial complexes and technical culture buildings (warehouses, infrastructural buildings, etc.) had been a neglected segment of building heritage until fifty years ago. After a series of demolition and huge protests of citizens and professionals in western European countries since 1960s, a new interdisciplinary field of research of Industrial Archaeology has developed. The cradle of industrial revolution, Great Britain, is also one of the most significant countries for the development of the Industrial Archeology. Namely, the first technical culture site ever inscribed on the UNESCO World
Heritage List was Ironbridge [1] in 1986. Since then the number of technical culture sites and industrial complexes inscribed on the UNESCO World Heritage List is increasing. Consequently, the process of registration of industrial complexes at national lists of registered monuments ("listed buildings") has been arising as well.

Industrial complexes and technical culture complexes are significant morphological elements of the city. Their ascetic-aesthetic component anticipated the development of the structural features and modern architecture. They were situated originally in peripheral areas of the city, but through decades urban fabric had wrapped the structures up, which are 
nowadays integrated within the wider centre of numerous towns. As a result of de-industrialization, intensive in recent decades, they have remained empty and neglected. This period is a kind of functional "vacuum" - in between the termination of the original production function and initiation of new functions -is a period of decay and devastation. On the other hand, their large size, quality of the structural features, and significant morphological component within contemporary city (and even region), indicate wide spectra of possibilities for new uses. The most prominent examples within Europe are: Tate Modern in former oil-fired power station, in London (designed by architects Herzog \& de Meuron), IBA Emscher Park in Ruhr region in Germany, Gasometer complex in Vienna, etc. Those and many other regeneration projects are a showcase of a huge potential of redundant industrial complexes which can be refined by intervention of creative architects, and can generate new qualities of urban life.

This paper focuses on the two European towns and showcases: Bilbao in Spain and Zagreb in Croatia. Former industrial city of Bilbao is nowadays a symbol of contemporary architecture featured by Guggenheim Museum and designed by Frank Ghery. The extravagant project of Gehry's started the reformation of the Bilbao with growth of tourism and profit in general. Beside the urban regeneration, it started the trend of star-architects building their masterpieces one next to another along the river Nervion. It featured urban regeneration and numerous other examples of the contemporary architecture. This paper focuses as well on conversion of former winestorage for mixed-use complex designed by Philippe Starck. The initial idea of the project was to revive the dying neighbourhood because of the gentrification caused by the Guggenheim Museum.

Zagreb intensive development in recent 150 years is based on industrialization process. After intensive deindustrialization, regeneration of redundant industrial complexes and technical culture buildings is segmented. Although the most prominent regenerations are significant architectural achievements winning the most prominent architectural awards, numerous complexes are awaiting for the conversions. Many of them are left to decay, or were demolished promptly, offering attractive location for new buildings that have been raised. This paper focuses on two complexes of technical culture buildings in Zagreb, presenting early conversion versus still unsolved regeneration. The first one is the avant-garde example of conversion of Tannery building for the Glypthotek of Yugoslav, i.e. Croatian Academy of Science and Art. The other example is Zagreb Fair, which realization since 1955 has initialized urbanization of late modern New Zagreb. Decay of Fair function, led to provisory or designed conversion of pavilions for new purposes, but the integral regeneration still is still missing.

\section{Examples of Intervention in Brownfield Area and Regeneration of Technical Culture Buildings in Bilbao, Spain}

Ever since its foundation in the 14th century, Bilbao was a commercial hub of great importance in Spain due to its port activity based on the export of iron extracted from the Biscayan quarries.

During the nineteenth and early twentieth century, Bilbao experienced heavy industrialization and thus became the second largest city and industrial region of Spain, after Barcelona [2]. Today, Bilbao is transformed into a city of services with a strong urban, social, economic and aesthetic regeneration, starting with the iconic Guggenheim Museum in 1997, and numerous other investments such as airport terminal, subway systems, cultural center Alhóndiga and investment in the revitalization of the industrial waterfront - Port of Bilbao.

The new history of Bilbao starts in the early eighties. Still under the influence of trauma caused by the industrial crisis, the Basque government has approved a strategic plan for revitalization to promote services and tourism as activities that could help Bilbao become a modern European cultural city. To that end, non-profit organizations such as Bilbao Ria 2000 have been established to monitor the recovery process of urban areas [3].

Today's industrial transformations of Bilbao are primarily associated with the phenomenon of "labelled" architecture. Therefore from the nineties, Bilbao becomes the city in which each of the stararchitects wanted to "lay" piece of their work. Some architects had already succeeded, such as Rafael Moneo, Norman Foster, Arata Isozaki, Álvaro Siza Vieira, Frank Gehry, Zaha Hadid, César Pelli.

The process of de-industrialization spurred the conversion of many former industrial areas into modern public and private spaces that are designed by world-renowned architects and artists. Abandoibarra, the area of intense renewal process, is the location of the Guggenheim Museum, but of other Bilbao landmarks such as the Isozaki Atea towers, the Iberdrola Tower and Euskalduna Conference Centre and Concert Hall. Iberdrola Tower, built by César Pelli, is the $165 \mathrm{~m}$ high skyscraper, which makes it the highest building in Bilbao. Nearby is the emblematic Deusto Library built by Rafael Moneo in 2008 and Euskalduna Conference Centre and Concert Hall built by Federico Soriano and Dolores Palacios, whose façade composed of different materials stands out in the city of Bilbao. Zorrozaurre is the next area of reconstruction after the Zaha Hadid's master plan. The current peninsula will be transformed into an island connected to the mainland with several bridges with many residential and commercial buildings [4]. 


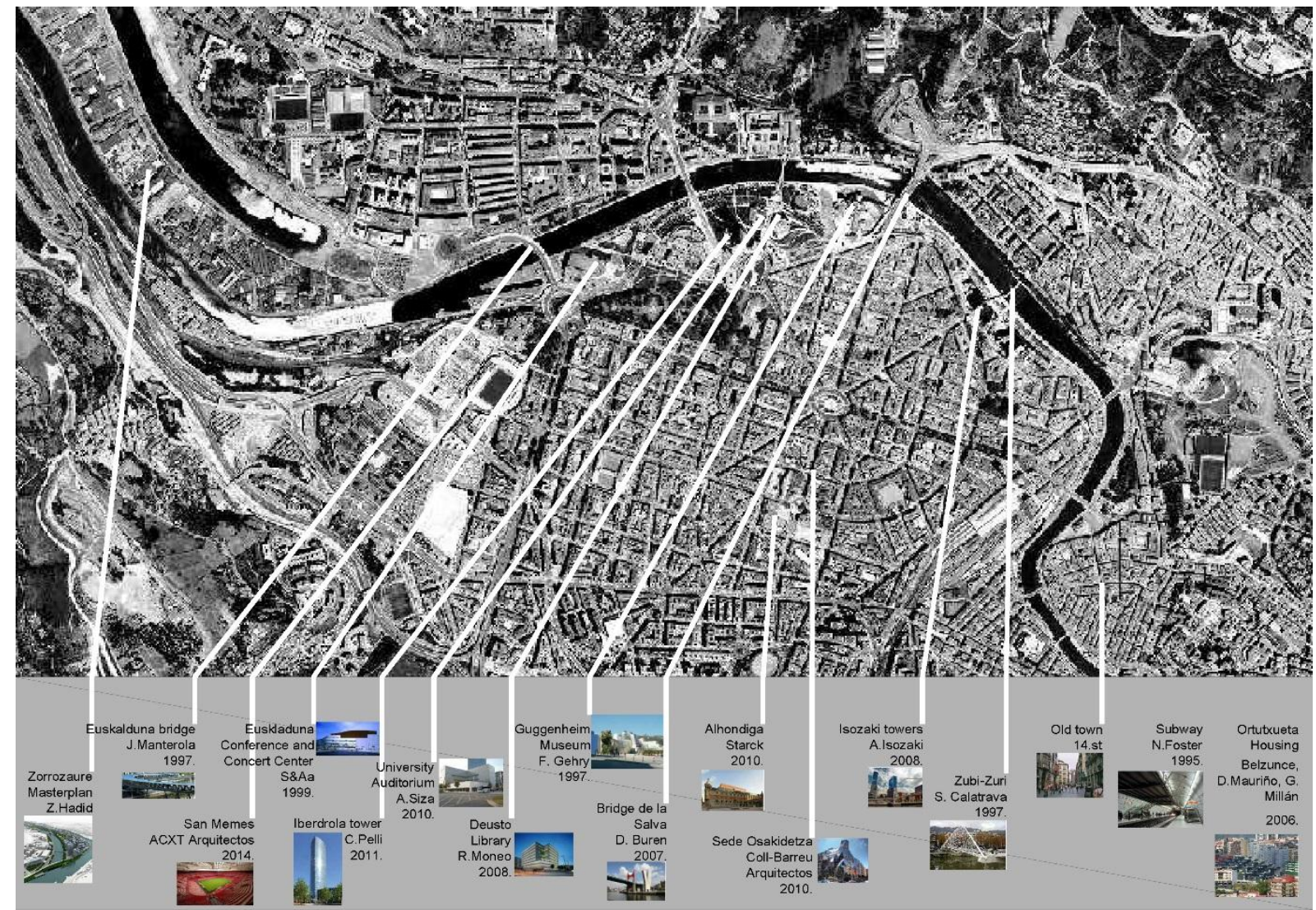

Figure 1: Map of Bilbao showing the most important showcases and their architects

The main example within the Bilbao industrial regeneration is the Guggenheim Museum, which is located in the old wharf and timber storage. Literally overnight, the small city became one of the most popular destinations in Europe [5]. Guggenheim Museum was built at the former industrial port on the river Nervion and was officially opened on 18 October, 1997. In order to bring the Guggenheim Foundation in the city, the Basque government agreed to pay over \$ 200 million of various expenses such as the construction and exhibitions of Foundation Solomon R. Guggenheim because they believed that such facility could be the main source of city's income [6].

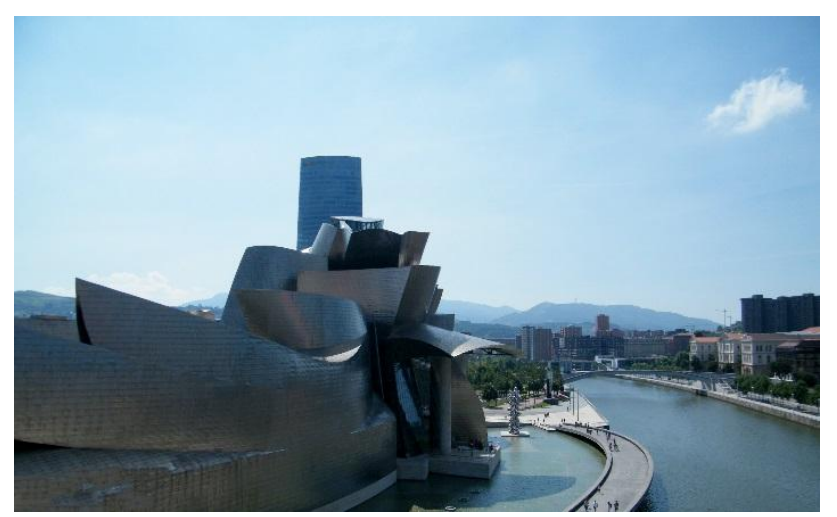

Figure 2: Guggenheim Museum in Bilbao, location of former wharf on river Nervion
Architect Gehry, chosen by the Guggenheim Foundation, was given the task to make something completely new and unseen. The final shape is not arbitrary, but as Gehry says, "the randomness of the curves are designed to catch the light" [7]. The museum is integrated into the urban tissue in a way that its materials combinations (stone, glass, titanium) develop façade as the ode to the former industrial town on the river.

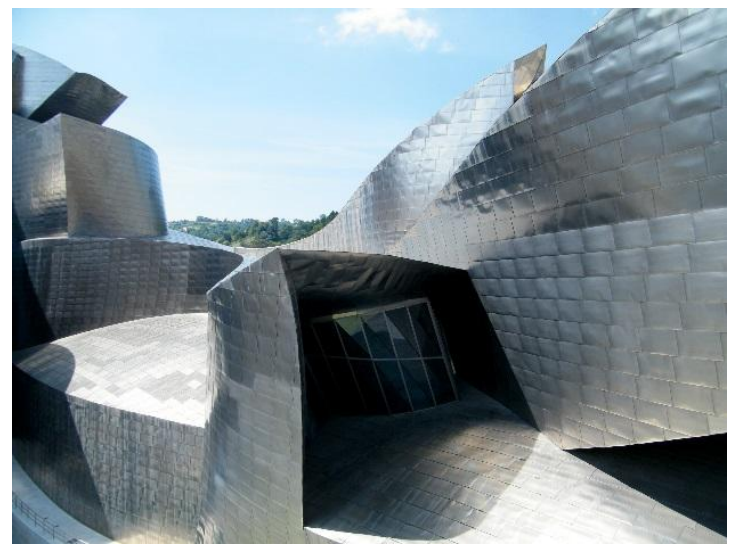

Figure 3: Guggenheim Museum in Bilbao, titanium facade

More than half of the museum surface is dedicated to the exhibition space with over nineteen galleries, ten of which follow the classic octagonal plan. In the largest gallery $(30 \mathrm{~m} \times 130 \mathrm{~m})$ is located in 
a permanent installation by Richard Serra. Since the Guggenheim Museum opened its doors, it has been proclaimed as one of the most spectacular buildings of the world, which remained to this day.

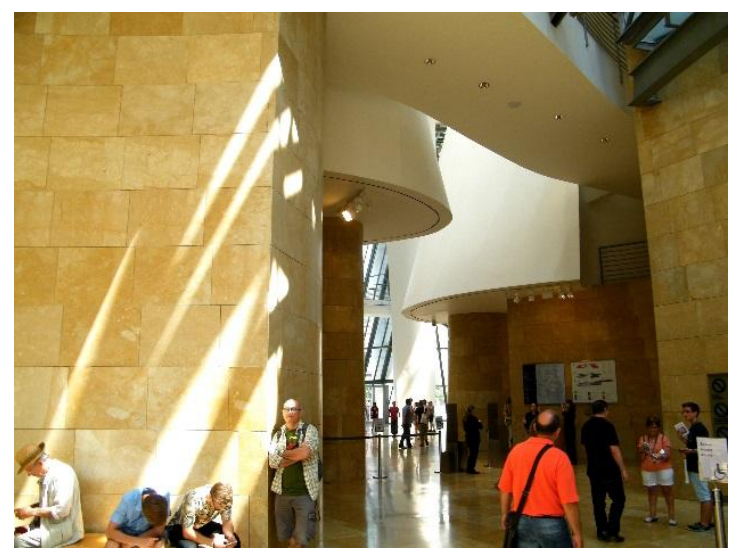

Figure 4: Guggenheim Museum in Bilbao, interior showing the use of materials and importance light

Another significant example of regeneration is the renovation of industrial heritage is Alhóndiga whose redevelopment is led by Philippe Starck, in cooperation with Thibaut Mathieu. The building opened to the public in 2010 as a multipurpose cultural-leisure centre [8]. Alhóndiga is just one link of Bilbao renewal and urban regeneration of the entire area in the old industrial city [9].

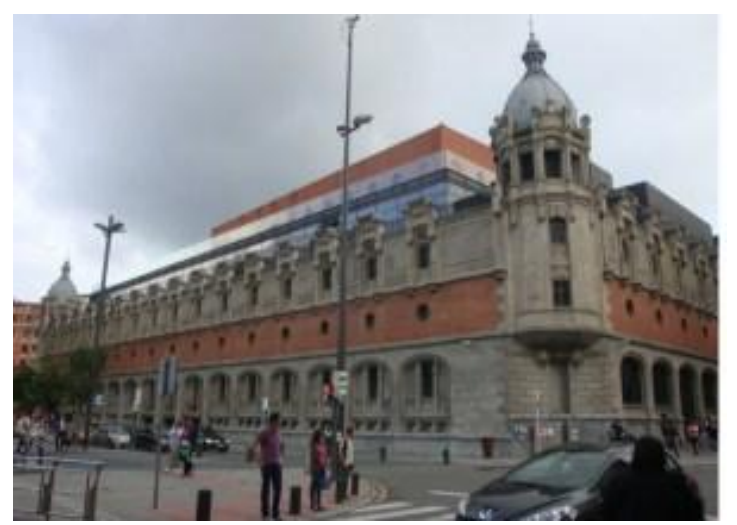

Figure 5: Alhóndiga in Bilbao, exterior showing the preserved envelope from 1909

Phillipe Starck's idea was to humanize the building and turn it into a new cultural and entertainment centre for the Bilbao inhabitants. The project is very user-sensitive, so the architect himself, except the building façade which had already existed before, has designed all of the details in the urban and building scale - a total design in the true sense of the word [10]. After the destruction of the warehouse in the fire in 1919, the building was abandoned. In the eighties and nineties, the old warehouse was used as a parking lot, but after 1993, the city council finally started to consider its conversion. The first serious steps towards regeneration into a new social centre were taken in 2000, after the new traffic regulation.
The concept of Alhóndiga conversion could be summed up by Latin saying "Mens sana in corpore sano" [11], meaning that all of the users are invited to achieve the ideal state of balance between body and mind [12]. The new city leisure and culture centre can be divided into the three main theme spaces physical exercise, media and leisure activities. Its spectacular entrance area [13], with various columns [14], differs in heights and facilities. Alhóndiga consists of a multiplex cinema, fitness centre, mediatheque, library, swimming pool, gym, shops, restaurants and business area distributed either in one of the three "floating" boxes or in the basement. In front of the main entrance is the park forming the entrance plaza and on the roof is a relaxation area and an indoor pool with a glass roof and floor [15].

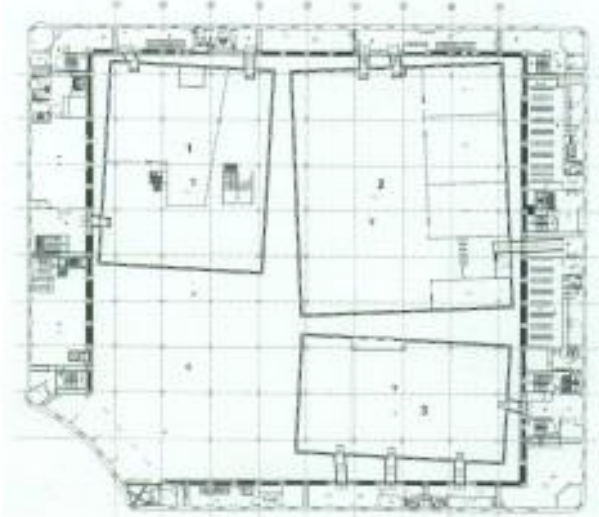

Figure 6: Alhóndiga in Bilbao, plan with the positions of "floating" boxes [16]

Alhóndiga renewal project is one of the most effective and most sustainable among similar projects, as regardless of the unique approach of the architect, the appearance and architectural value of the original building are still preserved. Beside the successful building regeneration itself, the urban regeneration of the wider area has been accomplished, which is nowadays even more important. Therefore, Abando neighborhood and Plaza Arriquibar are again an active part of the Bilbao, as they were during the industrialization period.

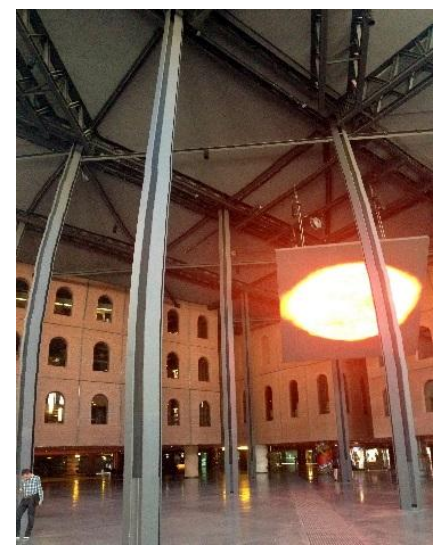

Figure 7: Alhóndiga in Bilbao, interior of "Gran central plaza" with TV screen and visible construction, different heights and various columns supporting "floating" boxes 
Examples of Regeneration of Technical Culture Buildings in Zagreb, Croatia

Zagreb was established in 1850 by unification of two historic nuclei: bishop's Kaptol and trade and citizens Gradec. Development of the city was rapidly accelerated since the railway was built in 1862 and by the rapid industrialization which followed. Block structure of historicist Lower Town is ennobled by integration of Green Horseshoe system of parks with most prominent cultural and high education buildings. Modernist architecture dominates in the newer part of the city which grew rapidly. Due to de-industrialization in the recent decades, redundant industrial complexes nowadays present an important element of the Zagreb morphology. Awarded quality examples of regeneration of the industrial heritage clearly indicate its potential (for example Lauba - house for people and art in former Textile Warehouse). Meanwhile, the numerous redundant plants realistically present actual difficulties of the regeneration process. The revised relationship towards industrial heritage would enable more efficient transformation of abandoned industrial complexes into urban "generators", simultaneously preserving the identity formed in the enormous growth and development of Zagreb over the past 150 years.

Vacant complexes of distinctive morphological value are situated in the wider areas of historic Zagreb nuclei and are seen as a huge potential that might be converted to new uses. Although many production facilities in Zagreb were demolished, the potential of abandoned technical complexes was recognized quite early in the 20th century.

The Zagreb-based most powerful industrial plant, the Tannery complex, was converted into a gallery space for a plaster cast exhibition of the Croatian Academy of Sciences and Arts (1937-1945). A set of coincidences led to this earliest conversion of an industrial complex into a facility for cultural purposes. The complex was built in phases (19th 20 th c.) in the valley of Medveščak stream and gradually developed into the most powerful 19th century industrial plant in Zagreb. Situated only $200 \mathrm{~m}$ north form the Zagreb cathedral, it had heavily polluted air and water in the centre of Zagreb. The first ecological protests of citizens in the 19th century led to its end. Dr. Antun Bauer's donation of plaster cast exhibits to the city in 1937 raised the issue of their housing. The Tannery complex was considered as a perfect solution due to its large spaces, flexible structure and minimal interventions needed to house the collection.

The exhibition space for the collection of sculptures of the Croatian Science and Art Academy was opened immediately after the end of the Second World War in October 1945.

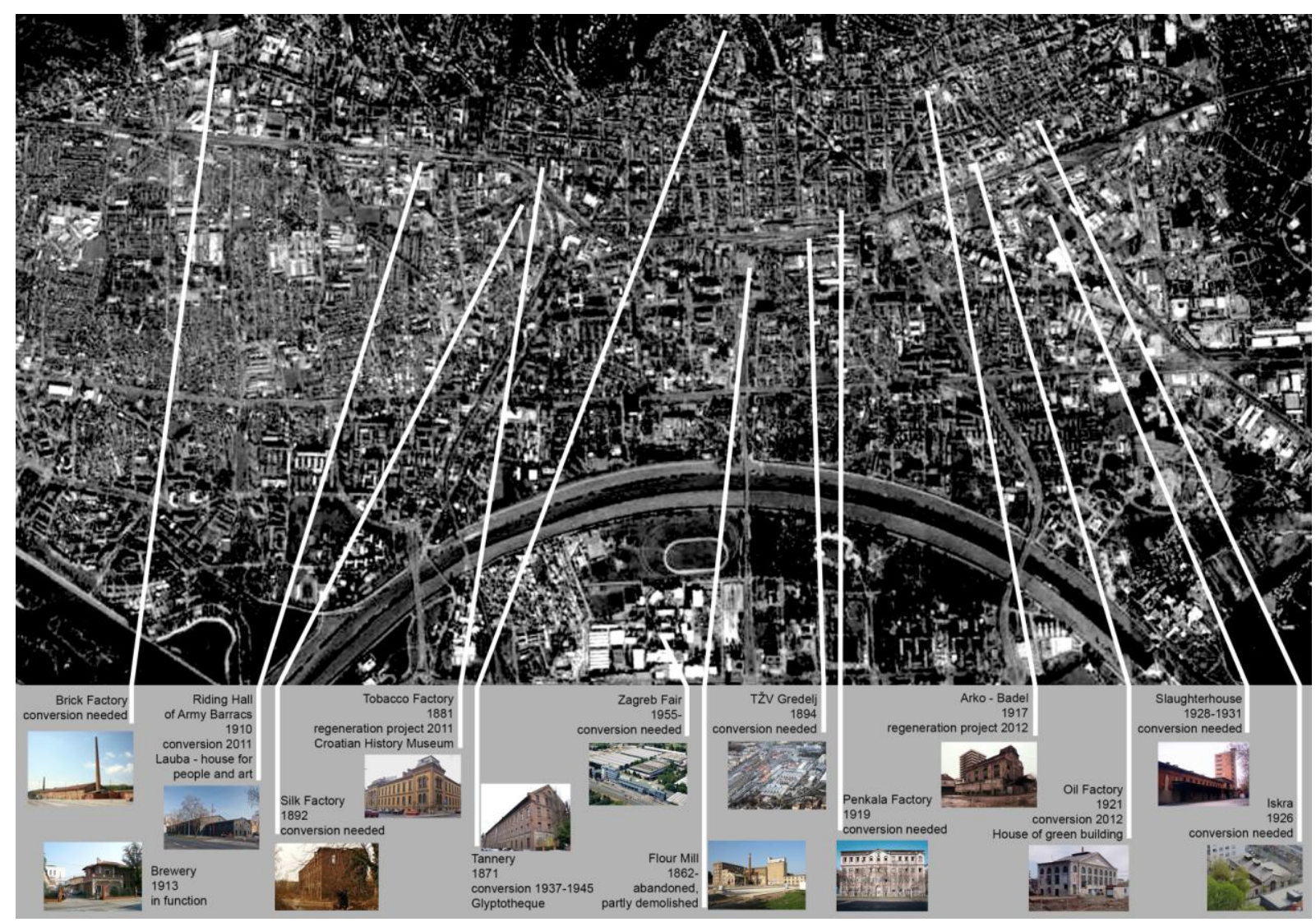

Figure 8: Redundant industrial sites in Zagreb, potentials for new functions 
Permanent and contemporary exhibitions are taking places there even nowadays, transforming the Tannery into a generator of urban life and culture in this specific contact zone within the Upper Town of Zagreb.

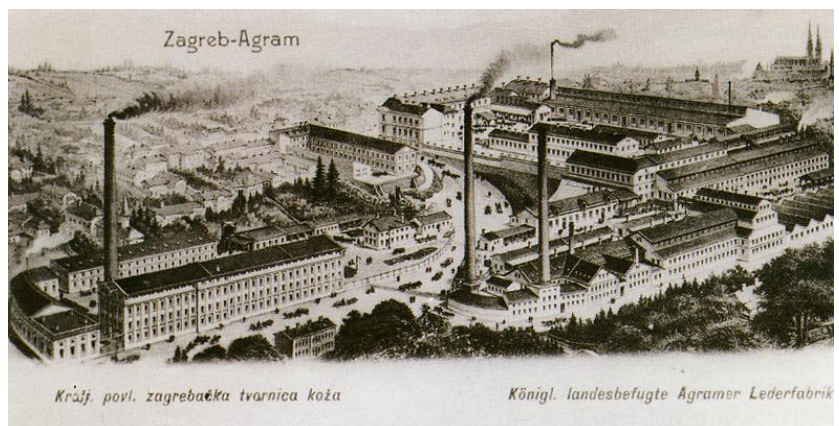

Figure 9: Tannery complex in Zagreb, idealized projection $19^{\text {th }} / 20^{\text {th }}$ century

The early example of the regeneration, i.e. the conversion of an industrial complex to cultural uses is an avant-garde example within Croatia and even Europe.

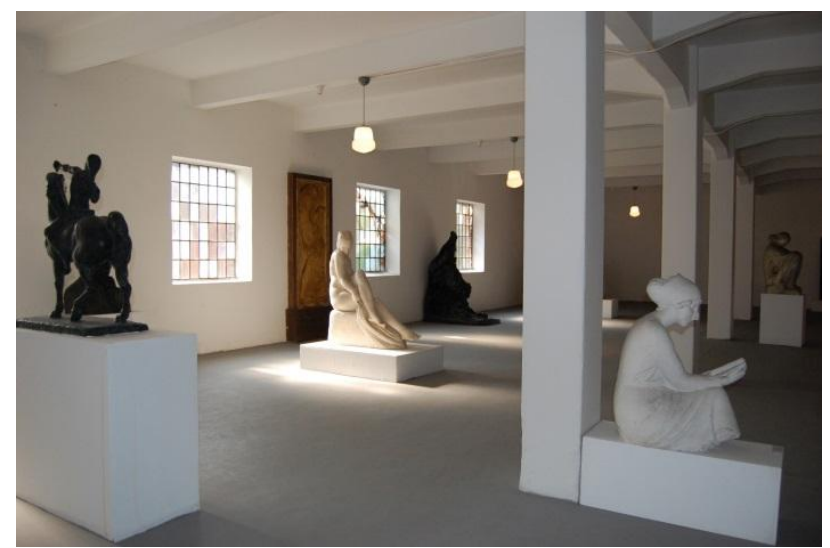

Figure 10: Tannery complex in Zagreb converted into a gallery space for a plaster cast exhibition of the Croatian Science and Art Academy (1937-1945)

After the setup of railway system in Zagreb, in the first phase by Austrian railways, and in the second phase by Hungarian railways, industry areas were built intensively close to it. It was related to the secondary aspect of location of industrial areas, due to the importance of transportations of raw materials and final products. Nowadays, these complexes are part of the wider centre of Zagreb, and after intensive de-industrialization they remained as silent witnesses of the prosperous period of Zagreb history throughout of 19th and 20th century. Although there are many quality examples of conversions of industrial heritage, they are mostly only segmented regeneration projects.

South from the Sava river, New Zagreb urbanization was initiated by the realization of a huge fair complex (Zagreb Fair) since 1955 [17]. The initial complexes of technical culture realized in New Zagreb, clearly illustrate the thesis that the construction of buildings of technical culture at the perimeter of urban areas initiates the construction and urbanization that, hitherto unattractive peripheral areas of the city.

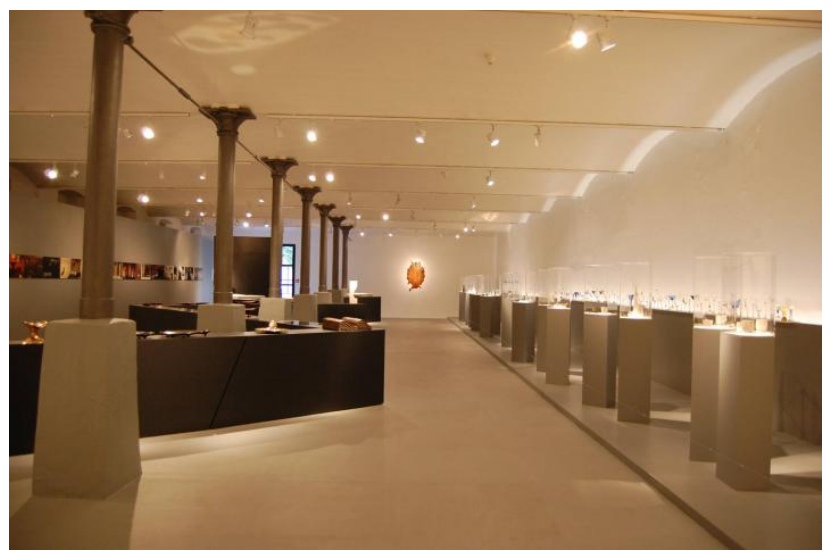

Figure 11: Tannery complex in Zagreb converted into a gallery space for temporary exhibitions (Fabijanić-Kogoj exibition at ground floor, 2010)

The urban plan of South Zagreb (Urban Institute Zagreb, 1962) was designed for approximately 250,000 inhabitants in the total area of 2.350 ha. It was structured according to the spatial conception of urban development of the city into four residential areas, on the system of "cardodecumanus", which form the basic transport concept. A series of parallel roads of lower rank is determined basically cassetted structure of the New Zagreb tissue [18].

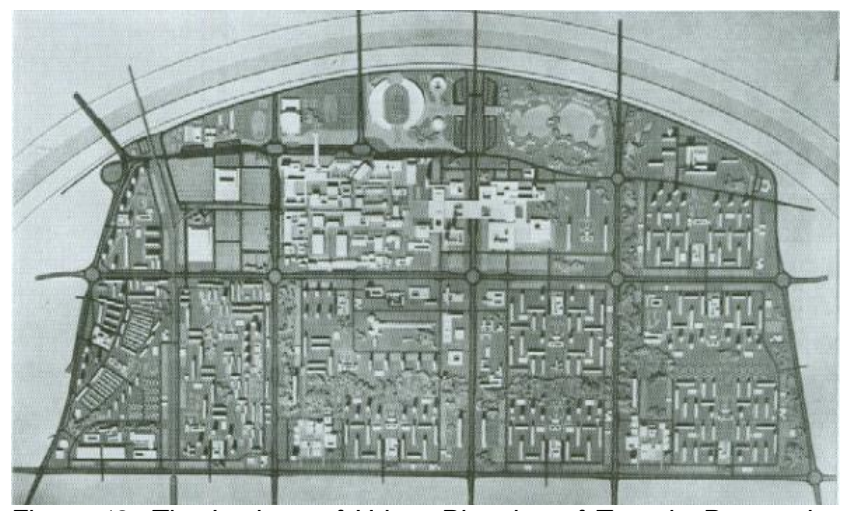

Figure 12: The Institute of Urban Planning of Zagreb, Proposal of Master Plan of New Zagreb, 1962, model

Zagreb Fair was planned in 1955 at a new site southern from the Sava river. The Fair was planned initially by Marijan Haberle (1955-1956), by pavilion structure along the central Avenue of the Nations. The second phase was planned by Božidar Rašica (1956-1964) according the concept of grading spatial scales and intention of active integration of fair into the surrounding urban matrix being built since 1960s. "It was this building of the new fair that 
provided the infrastructural impetus to the origin of South or New Zagreb - Novi Zagreb - the greater modernist expansion of the city" [19]. Pavilions were designed by both, Croatian and foreign architects, and some of them are presenting the best Croatian architecture realizations of the period of late modern. The most prominent are pavilions designed by Ivan Vitić and Božidar Rašica.

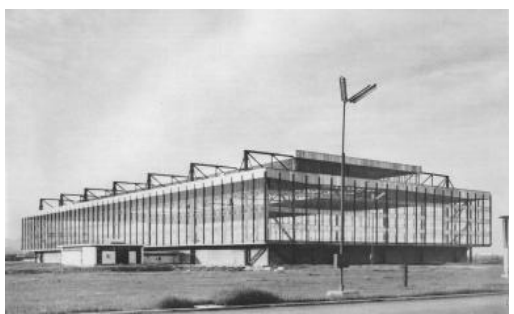

Figure 13: Božidar Rašica, Mechanical Engineering pavilion, Zagreb Fair, Dubrovnik Av. 15, Zagreb (1957)

The Mechanical Engineering pavilion was designed by Božidar Rašica in 1957. Transparent cubical form integrates abstract design with pavilion`s function of showcasing big machines. The steel structure is a minimalist construction.

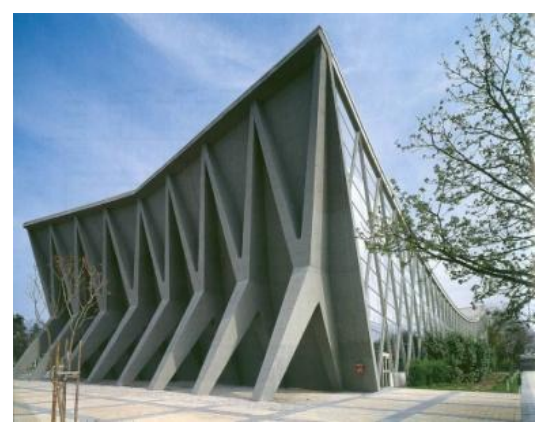

Figure 14: Ivan Vitić, Exhibition pavilion 40, Zagreb Fair, Dubrovnik Av. 15, Zagreb (1956-1958)

Pavilion 40 was designed by Ivan Vitić in 1956-1948, in cooperation with constructionist Krunoslav Tonković, the greatest bridge builder of a time. Integration of architectural design and construction system is unique. Suspended roof is stabilized by concrete gable walls reinforced by ribs,

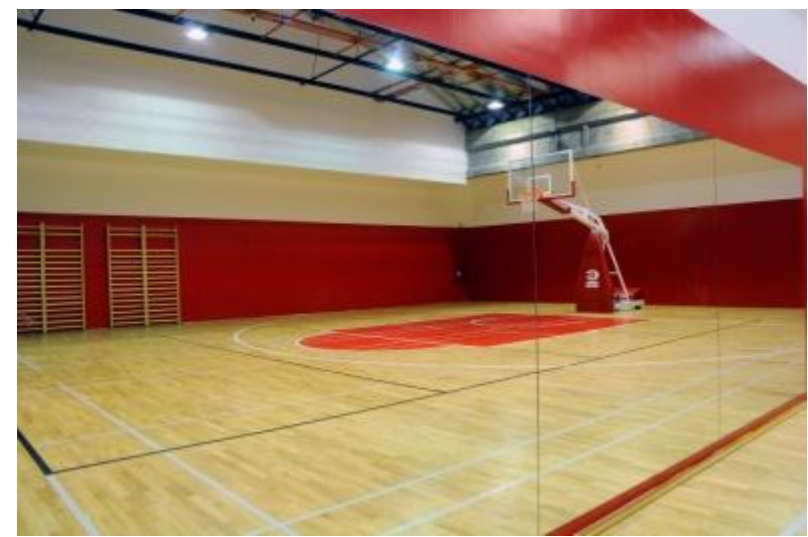

Figure 15: 3LHD, Cedevita Training Camp, Zagreb Fair, Dubrovnik Av. 15, Zagreb, 2012 (regenarated Pavilion 2 of Zagreb Fair, designed by Božidar Rašica in 1970s) and longitudinal glass façade with rhomboid steel structure.

Although Zagreb Fair was the third most important European Fair in 1958 [20], since then has lost its significance, and primary power. Many pavilions were provisionally converted for other purposes. Rašica`s Mašinogradnja Pavilion is being used as a tennis court.

Transparent glass surfaces are covered by textile, diminishing original quality of the glass cube building. Vitićs pavilion was used in 1978 for the European Figure Skating Competition, and ever since it has been used as a skating rink. Due to the provisional function and the moisture in the air, the structure of this unique pavilion is getting gradually damaged. South western pavilion 2 on Zagreb Fair designed by Božidar Rašica in 1970s was transformed into basketball training camp for the Cedevita basketball team in 2012. The spatial framework of the existing two grid pavilion was used to house a gym with two basketball courts and retractable telescopic stands, a handball court and a small gym for aerobics [21]. This one of the rare positive example of regeneration within Zagreb Fair, which presents a quality design by 3LHD architects. This complete realization of regeneration versus numerous provisional solutions which are not respecting remarkable design realizations, is presenting the possibilities of quality regenerations within Zagreb Fair.

The two examples present different stages of conversions of the technical culture buildings in Zagreb. Gallery building is the avant-garde example of conversion of industrial complex, i.e. Tannery building for the Glypthotek of Yugoslav, presently Croatian Academy of Science and Art. It presents the closure of paradigmatic cycle of development most powerful industrial plant of Zagreb in 19th century, and its conversion for culture purposes. Realized even before the earliest conversions of technical culture buildings in western countries, it is still not affirmed avant-garde example of conversion of redundant industrial complexes within Europe.

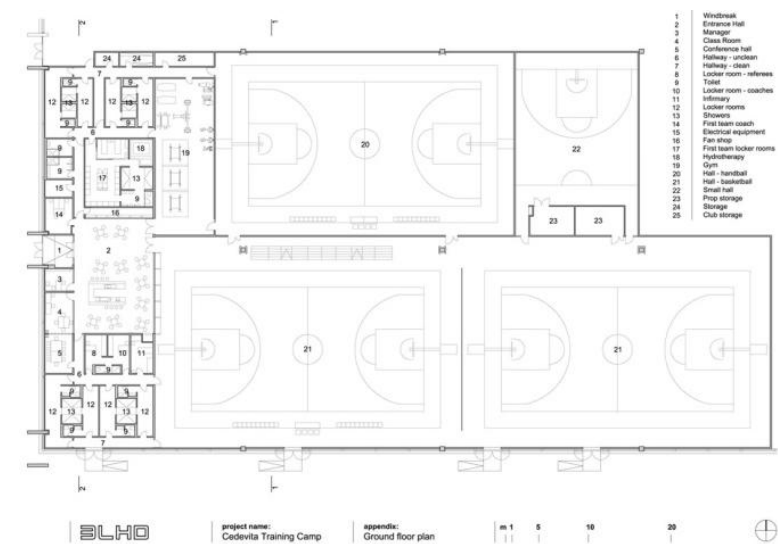


The other presented example of Zagreb Fair has initialized urbanization of modernist New Zagreb since 1955. Contemporary decay of the Fair function at this location, led to provisory and designed conversions of pavilions for new purposes. All of them are only partial interventions within huge structure, which position lies within wider centre of contemporary Zagreb, and in very centre of New Zagreb. Because of the valuable location, it is necessary to affirm the importance of the complex. Its urban role is nowadays neglected. Focusing backwards former market and fair complexes, their importance is significant within the city of Zagreb. All the former fair and markets locations were transformed to the new public spaces and focuses of Zagreb contemporary life [22]. The adequate conversion of this complex remains to be solved.

\section{Discussion}

Deindustrialization, a process typical of Western countries in recent decades, has considerably affected Spain and Croatia as well.

Bilbao was the example of the successful urban regeneration of the former sleepy industrial city. This city in Northern Spain gets a new museum housed in a building already called, on its completion at the end of the 20 th century, the most important building of the 21st century. It has turned Bilbao into one of the most popular destinations in Europe. This shiny radical new building became the center of the urban regeneration process, and it has also defined a city [23]. Since the surrealistic structure of titanium opened its doors in Bilbao, nearly seventeen years ago, a new era for the shabby industrial city has begun. The interest of people visiting Bilbao was primarily to see the museum building, and secondary the art inside. The structure influences the economy as a new catalyst, "a new aphrodisiac." Following that, almost ten years after the Guggenheim Museum, a new building called Alhóndiga was opened.

Philippe Starck renewed old wine warehouse, and thereby revitalized the space of dying Abando neighbourhood because of gentrification caused by the Guggenheim Museum and the lack of content. The result of the reconstruction and the new urban regulation significantly enriched the urban tissue and all this has contributed to sustainable development and progress. Alhóndiga became the heart of the district where everybody wants to live. Preserved envelope, seemingly simple interior with many unexpected details made this building from 1909 so intriguing both to professionals and amateurs.

Municipalities and non-profit organizations are hoping to increase profits and tourism of dilapidated industrial cities by using the star-architects projects. With the fame and key success of the Guggenheim Museum in Bilbao, where the economic decline led to enormous financial growth and prestige, the media started talking about the so-called "Bilbao effect". Incredible number of tourists visiting Bilbao introduced a trend that other cities without historical and cultural values tend to look to. Bilbao became a positive role model that shows what vision, imagination and investment can achieve [24]. However, people often forget about the dark side of the "Bilbao effect". Sudden change has transformed the city in an unexpected manner, even undesirable one. The economic stratification and social exclusion start to grow rapidly where the transition of the new economic elite exceeds the level of ordinary gentrification. Shock of growth causes the unfortunate side effects of urban planning and democratic participation.

Many cities will have to endure great sacrifices in terms of gentrification, but most will be willing to accept such sacrifice in exchange for profits and tourism. Bilbao effect was not a success in other cities that tried to use the same recipe for the profit. Anyway, the trend to expand cultural institutions in order to accelerate economic transformation of industrial cities comes to a slowdown because of the global financial collapse [25].

Deindustrialization, a process typical of Western countries in recent decades, has considerably affected Zagreb as well. It was even more emphasized due to the Croatian War of Independence in the 1990s and privatization, conversion from a socialist to capitalist political system. Urban regeneration of Zagreb was postponed due to the war, and prospectus years at the turn of Millennium were interrupted by actual economic crises. Zagreb is not characterized by realization of prominent star-architects in 20th or 21st century, although there have been significant competition projects by Adolf Loos and Alvar Aalto since the beginning of 20th century and Norman Foster and Zaha Hadid at the beginning of 21st century [26].

Industrial complexes originally built in peripheral area of city are nowadays integrated within central zones and are significant morphological elements of wider centre of Zagreb. After losing their primer function, they remained as the silent witnesses of the rapid development of modern Zagreb. Nowadays they are mostly left to decay. Redundant industrial complexes are mostly waiting for conversion, although there are examples of provisory "bottom-up" interventions, or regenerations realized upon architectural competition.

Some regeneration is outstanding even within European context. Conversion of the former Tannery in Zagreb city centre 1937-1945 into a Gallery of Sculptures presents an avant-garde example of an 
industrial complex converted to cultural uses. Although there are many quality examples of conversions of industrial heritage, they are mostly only segmented regeneration projects. Zagreb Fair is having a great potential for functional and structural regeneration that has begun by construction of the Museum of Contemporary Art. Beside much provisional regeneration within Zagreb Fair, regeneration of Pavilion 2 by 3LHD for Cedevita Training Camp is indicating positive direction for future solutions. Due to extreme importance of the complex within urban fabric of Zagreb and great significance that former market and fair complexes have within Zagreb, its huge potential should be adequately solved.

In conclusion, urban regeneration should be considered seriously, and lead to transformation to contemporary city of 21 st century. Bilbao and Zagreb are cities with different premises. Urban regeneration of Bilbao initialized by realization of star-architect was followed by numerous other positive conversions. Although many other cities tried to copy the matrix, in has not been successful. That indicates that there is not matrix, or role model that could be copied. Each city is having its own character and should find its own way of urban regeneration. Time dimension is very important as well, while with time progress chances of preservation and regeneration of historic complexes are diminishing (due to the danger of final destruction). On the other hand, numerous positive examples of regeneration of redundant industrial and technical culture complexes are presenting huge potentials for contemporary city and its urban regeneration. Integration of historical technical structure building and contemporary architecture intervention presents unique set of layers and identities, which are very inspiring for contemporary urban life.

\section{References}

1. Ironbridge is known throughout the world as the symbol of the Industrial Revolution. It contains all the elements of progress that contributed to the rapid development of this industrial region in the 18th century, from the mines themselves to the railway lines. Nearby, the blast furnace of Coalbrookdale, built in 1708 , is a reminder of the discovery of coke. The bridge at Ironbridge, the world's first bridge constructed of iron, had a considerable influence on developments in the fields of technology and architecture." http://whc.unesco.org/en/list/371

2. Gómez Pi-eiro, Francisco Javier; et al. Geografía de Euskal Herria: Vizcaya. San Sebastián, 1979:p. 291.

3. "BILBAO Ría 2000 - ¿Qué es?". Bilbao Ría 2000. http://www.bilbaoria2000.org/ Retrieved 25 December 2015

4. I-aki Azkuna, "Seguirá quedando claro el estilo de Zaha Hadid", 4 February 2010, El Correo. Retrieved 27 December 2015.

5. Jacob Bacharach: "The Bilbao Effect" 8 April 2014. http://www.sustainablecitynews.com/ Retrieved 26 December 2015.

6. Alan Riding: "A Gleaming New Guggenheim for Grimy Bilbao",
The New York Times, 24 June 1997.

7. Artika Aggarwal, Divya Bansal:. "Frank Owen Gerty", http://www.archinomy.com/ Retrieved 27 December 2015.

8. Philippe Starck - Alhóndiga Cultural and Leisure Center, 10 September 2010. http://archiblock.com/

9. Rehabilitación de la Alhóndiga de Bilbao (2002-10), 25 April 2014, https://proyectos4etsa.wordpress.com/ Retrieved 27 December 2015.

10. Alhóndiga, Bilbao, Bizkaia, May 2010.

http://www.starck.com/en/architecture/

11. A healthy mind in a healthy body.", quote from Juvenal's Satire $\mathrm{X}$

12. Alhóndiga, Bilbao, Bizkaia, May 2010.

http://www.starck.com/en/architecture/

13. "Gran central plaza" with large screen TV, which mainly shows the Sun, the center Alhóndiga universe.

14. 43 columns designed by Lorenzo Baraldi, who found inspiration in different periods and materials such as marble, bronze, wood, brick, terracotta, stone...

15. Philippe Starck - Alhóndiga Cultural and Leisure Center, 10 September 2010. http://archiblock.com/

16. Rehabilitación de la Alhóndiga de Bilbao (2002-10), 25 April 2014, https://proyectos4etsa.wordpress.com/ Retrieved 27 December 2015.

17. Testing station of Shipbuilding Institute was built previously after a project of Marjan Haberle 1949-1955.

18. Zrinka Barišić Marenić: Prolegomena opusu urbanista Mirka Maretića. Prostor: znanstveni časopis za arhitekturu i urbanizam, Zagreb. 2013;2(46):274-291.

19. Maroje Mrduljaš, Vladimir Kulić (edts.): Unfinished Modernisations - Between Utopia and Pragmatism. Zagreb, Croatian Architects' Association, 2012: pp. 29-30.

20. After Milan and Hanover. Aleksander Laslo: Architectural Guide Zagreb 1898-2010, Arhitekst, DAZ, Zagreb, 2011:204-205.

21. Cedevita Training Camp

http://www.3lhd.com/en/project/cedevita-training-camp, Retrieved 23 December 2015

22. All former Zagreb markets in fact initiated the creation of new public spaces of Zagreb; historic markets were moved from St. Marko's Square and the square in front of the Cathedral at today's Ban Jelacic Square; further to Nikola Subic Zrinski Square

(Zrinjevac), Marshal Tito Square, Square of King Petar Kresimir IV, and Heinzelova Street, etc. Building in Novi Zagreb was initiated by the realization of the Zagreb Fair south of the Sava, which was moved from the previous locations along the Savska road (complex of Zagreb Fair, Haberle - Bauer, 1936-1939 (partially realized) and a pavilion extension of the Zagreb Fair (today Technical Museum) M. Haberle, 1949).

23. Jacob Bacharach: "The Bilbao Effect" 8 April 2014. http://www.sustainablecitynews.com/

24. Kriston Capps: "With the Louvre-Lens, a Curtain Call for the Bilbao Effect", 14 December 2012. http://www.citylab.com/

25. Kriston Capps: "With the Louvre-Lens, a Curtain Call for the Bilbao Effect", 14 December 2012. http://www.citylab.com/

26. Alvar Aalto projected Foundation hospital in 1931 and Adolf Loos Esplanade hotel in 1922. Contemporary architecture projects by Zaha Hadid and Sir Norman Foster were submitted for international competition for New Zagreb Airport recently, or Alvaro Siza design of Zorkovac Chapell, remained as project endeavors. Thom Mayne designed initial project, conceptual design for headquarters of Hypo Alpe-Adria Bank Complex, and prof. Boris Podrecca for mixed-use complex Cvjetno passage residential, which were realized and finalized by other Croatian, i.e. Austrian architects. 